\title{
Synthesis and Characterization of Ruthenium (III) Complexes with Substituted Nitrones
}

Khalaf I. Khallow

Eman M.H. Al-Bayate

Dept. of Chemistry, College of Education, University of
Mosul, Iraq.

Email: kikhallow@yahoo.com

\begin{abstract}
الخلاصة
حضرت سلسلة جديدة من المعقدات ذوات الصيغة RuCl 2 L(H

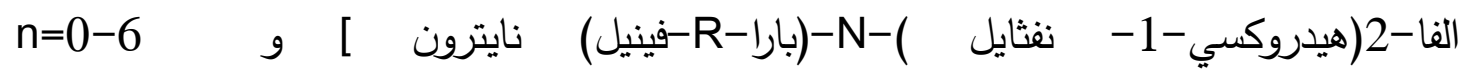
$\mathrm{R}=\mathrm{H}, \mathrm{Cl}, \mathrm{Br}, \mathrm{COCH}_{3}, \mathrm{NHCOCH}_{3}, \mathrm{NH}_{2}, \mathrm{CH}_{3}$

تم تشخيص هذه المعقدات بالتحليل الدقيق للعناصر(CHN) والموصلية والكهربائية المولارية والعزم المغناطيسي وكذلك طيف الاشعة تحت الحمراء والاطياف الاككترونية. اثبتت هذه الدراسات الطيفية بان الليكاند(L) يتناسق بشكل ثنائي السن احادي الثحنة مع ايون الروثينيوم(III) من خلال ذرتي الاوكسجين لمجموعتي النايترون والنفثوليك وبوجود ايوني كلوريد مع جزيئتي ماء ليعطي الثكل الاكثر احتمالا ثماني السطوح حول ايون الروثينيوم في جميع المعقدات ـ اثبتت دراسة التحليل الدقيق للعناصر في المعقدات اعلاه وكذلك اطياف الاشعة تحت الحمراء لها بوجود جزئات ماء خارج الكرة التناسقية .اشارت دراسات الموصلية المولارية الى السلوك غير الالكتروليتي للمعقدات.
\end{abstract}

\section{ABSTRACT}

New series of complexes of general $\left[\mathrm{Ru}(\mathrm{Cl})_{2}\left(\mathrm{H}_{2} \mathrm{O}\right)_{2} \cdot \mathrm{L}\right] \mathrm{nH}_{2} \mathrm{O}$; where $\mathrm{LH}=[\alpha-(2-h y d r o x y-1-n a p h t h y l)-\mathrm{N}-(\mathrm{p}-\mathrm{R}$-phenyl nitrone $] \mathrm{n}=0-6$ and $\mathrm{R}=\mathrm{H}, \mathrm{Cl}, \mathrm{Br}, \mathrm{COCH}_{3}, \mathrm{NHCOCH}_{3}, \mathrm{NH}_{2}$ and $\mathrm{CH}_{3}$ were formula synthesized and characterized by their elemental analysis(CHN), molar conductance, magnetic moments, infrared and electronic spectral measurements. The Ligand (L) acted as a bidentate, univalent toward the ruthenium (III) ion via the two oxygen atoms of, the nitrone and naphtholic groups, with the presence of two chloride ions and two aqua molecules the most probable octahedral geometry around each ruthenium ion in each complex.

Presented at the second conference on Chemistry, University of Mosul, college of Education, 17-18 Novamber-2013. 
The elemental analysis as well the infrared spectra revealed the presence of lattice water molecules outside the coordination sphere. Their molar conductance measurements revealed the non- electrolytie behavior of the synthesized complexes.

Key words: Ruthenium (III), Nitrone, Schiff base complexes.

\section{INTRODUCTION}

Many researchers referred that nitrones have special interest due to the broad spectrum of their applications and their successful use as building blocks in different synthetic strategies. They utilized in organic synthesis $(1,2)$, their function as inhibitor for corrosion of mild steel in organic acid media(3) and their uses as precursor for synthesizing compounds having antibacterial activities $(4,5)$.As well, their combination with either alkenes or alkynes cyclo-addition were achieved leading to the formation of new $\mathrm{C}-\mathrm{C}$ and $\mathrm{C}-\mathrm{O}$ bonds(6).Besides, new methods of nitrone group activation both with nucleophilic reagent by radical cation formation and with electrophilic reagent by generating dipolar stabilized anions were explored(7). The use of nitrones as ligands was also explored by preparing a series of complexes with transition metal ions (8). They are also used as a suitable ligand for heme model as in metalloporphyrine nitrone complex which was characterized by X-ray crystal structure (9). Recent years have witnessed a renewing interest in their chemistry mainly due to the development of the methods of preparation and subsequent applications $(10,11)$. The shortages of the $4 \mathrm{~d}$ metal ion complexes with nitrones has prompted us to synthesis and characterize a new series of substituted nitrones with ruthenium (III) chloride.

\section{EXPERIMENTAL}

1-Preparation of the ligands:The ligands were prepared according to the procedure in two steps (12) and the following procedure was adopted for the preparation of all the ligands in the present study :

Para-substituted nitrobenzene $(0.10 \mathrm{~mol})$ and ammonium chloride $(0.10 \mathrm{~mol}, 5.34 \mathrm{~g})$ were dissolved in $(100 \mathrm{ml})$ of Ethanol, cooled to $10^{\circ} \mathrm{C}$ and $(4.0 \mathrm{~g})$ of zinc powder was added with stirring for $2 \mathrm{hrs}$. The mixture was filtered to get the hydroxylamine in the filtrate to which $(0.07 \mathrm{~mol})$ of 2-hydroxy-1-naphthaldehyde was added. The mixture was stirred for 20 hrs in a dark place. The precipitate was filtered and washed several times with ether then dried. The following equations represent the methods for the prepared ligands with their melting points and crystallization solvents showed in Table(1). 
1. $P-\mathrm{R}-\mathrm{C}_{6} \mathrm{H}_{4} \mathrm{NO}_{2}+\mathrm{NH}_{4} \mathrm{Cl} \stackrel{\text { zn powder }}{\longrightarrow} p-\mathrm{R}-\mathrm{C}_{6} \mathrm{H}_{4} \mathrm{NHOH}$

2. $P-\mathrm{R}-\mathrm{C}_{6} \mathrm{H}_{4} \mathrm{NHOH}+\mathrm{C}_{11} \mathrm{H}_{8} \mathrm{O}_{2} \stackrel{\text { stirring} 24 \text { hrs in dark place }}{\longrightarrow} \mathrm{LH}$.

$\left(\mathrm{C}_{11} \mathrm{H}_{8} \mathrm{O}_{2}=\right.$ 2-hydroxynaphthaldehyde $), \quad \mathrm{LH}=$<smiles>Oc1cc2ccccc2cc1/C=N/c1ccc(P)cc1</smiles>

Table(1):The melting points and solvents for the prepared ligands

\begin{tabular}{|l|c|c|l|}
\hline Ligands & $\mathrm{R}$ & m.p. ${ }^{\circ} \mathrm{C}$ & Sol. \\
\hline $\mathrm{L}_{1}$ & $\mathrm{COCH}_{3}$ & 178 & Ethanol \\
\hline $\mathrm{L}_{2}$ & $\mathrm{Br}$ & 65 & Ethanol \\
\hline $\mathrm{L}_{3}$ & $\mathrm{Cl}$ & 55 & Ethanol \\
\hline $\mathrm{L}_{4}$ & $\mathrm{CH}_{3} \mathrm{CONH}$ & 140 & Ethanol \\
\hline $\mathrm{L}_{5}$ & $\mathrm{CH}_{3}$ & 85 & Acetone \\
\hline $\mathrm{L}_{6}$ & $\mathrm{H}$ & 68 & Ethanol \\
\hline $\mathrm{L}_{7}$ & $\mathrm{NH}_{2}$ & 214 & Chloroform \\
\hline
\end{tabular}

\section{Synthesis of the Complexes}

A solution of $(30 \mathrm{ml}, 0.005 \mathrm{~mol})$ of the corresponding ligand in hot ethanol was added to a stirred solution of $(20 \mathrm{ml}, 0.005 \mathrm{~mol})$ of $\mathrm{RuCl}_{3}$ in $25 \mathrm{ml}$ of $(60 \%)$ petroleum ether. A solution of $(0.5 \mathrm{M}) \mathrm{KOH}$ was added till become alkaline ( $\mathrm{pH} 7-9$ ) then was refluxed for $3 \mathrm{hrs}$ and then cooled to room temperature. The solid thus obtained was filtered, washed with ethanol and ether then dried.

\section{RESULT AND DISCUSSION}

The synthesized complexes were prepared according to the following equation:

$\mathrm{RuCl}_{3}+\mathrm{LH}$--- $\left(0.5 \mathrm{M} \mathrm{KOH} / \mathrm{EtOH} / \mathrm{H}_{2} \mathrm{O}\right)---->\left[\mathrm{RuCl}_{2} \cdot \mathrm{L} \cdot\left(\mathrm{H}_{2} \mathrm{O}\right)_{2}\right] \cdot \mathrm{nH}_{2} \mathrm{O}+$ $\mathrm{KCl}$

$$
\mathrm{n}=0-6 ; \mathrm{R}=\mathrm{H}, \mathrm{Cl}, \mathrm{Br}, \mathrm{COCH}_{3}, \mathrm{NHCOCH}_{3}, \mathrm{NH}_{2} \text { and } \mathrm{CH}_{3}
$$

The elemental analysis and some of the physical properties of the prepared complexes are listed in Table (II). They are stable in the solid state and soluble in dimethylformamide (DMF) and dimethylsulfoxide (DMSO) at room temperature. The molar conductivity values in DMF at $10^{-3} \mathrm{M}$ are lying in the range $(25-48) \Omega^{-1} \cdot \mathrm{mol}^{-1} \cdot \mathrm{cm}^{-1}$ indicating the nonelectrolytic behavior of all complexes (13) as shown in Table (II). 
The coordination sites of the ligands with the ruthenium (III) ion has been determined by careful comparison of the infrared spectra of the synthesized complexes with that of parent ligands as shown in Table(III). The free ligands showed important spectra in the regions (1077-1215), (1595-1599) and (1253-1356) attributed to $v(\mathrm{C}-\mathrm{O}), \mathrm{v}(\mathrm{C}=\mathrm{N})$ and $v(\mathrm{~N} \rightarrow \mathrm{O})$ respectively. The naphtholic $(\mathrm{C}-\mathrm{O})$ spectra were shifted to a lower values $(\Delta v=15-51)$ when compared with the spectra of their complexes.This is interpreted as due to the linkage of the ligand with $\mathrm{Ru}(\mathrm{III})$ ion through the oxygen atom of the naphtholic group $(14,15)$. The azomethine $(\mathrm{C}=\mathrm{N})$ spectra were found unchanged or very slightly changed $(\Delta v=0-2)$ comparing with that of the complexes and hence no indication of the coordination of the azomethine with the metal ion. Moreover, on comparison of the infrared spectra of the ligands and their complexes showed a significant shift toward a lower values by range (11-22) $\mathrm{cm}^{-1}$ in the nitrone $(\mathrm{N} \rightarrow \mathrm{O})$ group suggesting the involvement of its oxygen atom in the coordination with the ruthenium(III) ion(16). The presence of the coordinated and lattice water molecules in the prepared complexes were indicated by existence of broad bands in the range (3346-3432) $\mathrm{cm}^{-1}$, as it is not easy to distinguish between both types of water molecules since they appeared as a broad bands. As well, the coordinated water molecules in all complexes is indicated by existence of two somewhat weaker bands assigned as the $\mathrm{OH}$ rocking(r) and wagging $(\omega)$ vibrations at (827-849) and (633-694) $\mathrm{cm}^{-1}$ respectively(17).The $\mathrm{Ru}-\mathrm{Cl}$ bond is usually appeared in the region 200-300 $\mathrm{cm}^{-1}$ and this region is beyond the limit of the apparatus. In the low frequency region ,the spectra of the synthesized complexes Table(III) exhibited new bands which were not present in the corresponding ligands, were located at $503-531 \mathrm{~cm}^{-1}$ attributed to $v(\mathrm{M}-\mathrm{O})$ stretching(18).

The electronic spectra of the synthesized complexes are tabulated in Table(IV) and showed three bands at (526-623), (409-460) and (374397) $\mathrm{nm}$ as d-d transition which assigned to ${ }^{2} \mathrm{~T}_{2} \mathrm{~g} \rightarrow{ }^{4} \mathrm{~T}_{1} \mathrm{~g},{ }^{2} \mathrm{~T}_{2} \mathrm{~g} \rightarrow{ }^{4} \mathrm{~T}_{2} \mathrm{~g}$ and ${ }^{2} \mathrm{~T}_{2} \mathrm{~g} \rightarrow{ }^{2} \mathrm{~A}_{2} \mathrm{~g},{ }^{2} \mathrm{~T}_{1} \mathrm{~g}$ in the octahedral environment respectively $(19,20)$. The high intensity bands in the spectra of the synthesized complexes at (268354) $\mathrm{nm}$ were assigned to the charge transfer absorption between the ligands and the ruthenium(III) ion(21).

The magnetic susceptibility measurements of the prepared complexes are lying in the range (1.53-1.91) B.M. are indicative of single electron per $\mathrm{Ru}(\mathrm{III})$ ion suggesting their consistency with their octahedral arrangement(21).

In conclusion, the substituted nitrone ligands, in the present study, behaved as bidentate, univalent ligands coordinated through the two oxygen atoms of, the naphtholic and nitrone groups. The elemental analysis showed the existence of a number of lattice water molecules 
outside the coordination sphere. The presence of two chloride ions and two coordinated water molecules besides the bidentate ligands gave the most probable octahedral geometry around ruthenium (III) ion in each complex as depicted below:

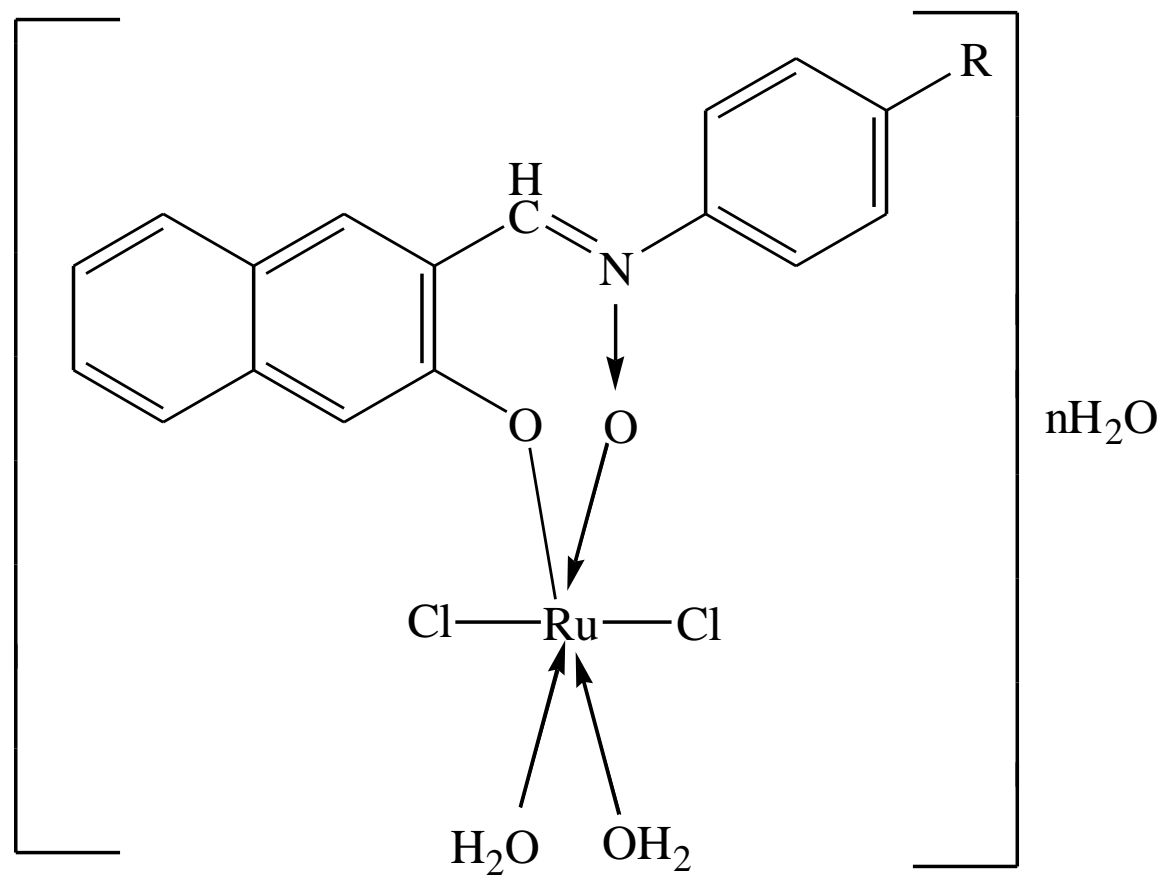

Table (II):Elemental analysis and physical properties of the synthesized complexes

\begin{tabular}{|c|c|c|c|c|c|c|c|}
\hline \multirow{2}{*}{ Complexes } & \multirow{2}{*}{ Color } & \multirow{2}{*}{ m.p. ${ }^{\circ} \mathrm{C}$} & \multicolumn{3}{|c|}{$\begin{array}{c}\text { Elemental analysis } \\
\text { Calc./(Found) }\end{array}$} & \multirow{2}{*}{ Yield\% } & \multirow[t]{2}{*}{$\begin{array}{c}\Lambda_{\mathrm{M}} \\
(\mathrm{DMF})\end{array}$} \\
\hline & & & $\mathrm{C}$ & $\mathrm{H}$ & $\mathrm{N}$ & & \\
\hline$\left[\mathrm{RuCl}_{2} \mathrm{~L}_{1}\left(\mathrm{H}_{2} \mathrm{O}\right)\right]$ & $\begin{array}{l}\text { Light } \\
\text { olive }\end{array}$ & $76-78$ & $\begin{array}{c}44.54 \\
(44.00)\end{array}$ & $\begin{array}{c}3.54 \\
(3.05)\end{array}$ & $\begin{array}{c}2.73 \\
(2.15)\end{array}$ & 73 & 47 \\
\hline$\left[\mathrm{RuCl}_{2} \mathrm{~L}_{2}\left(\mathrm{H}_{2} \mathrm{O}\right)_{2}\right] 4 \mathrm{H}_{2} \mathrm{O}$ & Olive & $66-68$ & $\begin{array}{c}32.87 \\
(32.31)\end{array}$ & $\begin{array}{c}3.73 \\
(3.24)\end{array}$ & $\begin{array}{c}2.75 \\
(2.10)\end{array}$ & 64 & 47 \\
\hline$\left[\mathrm{RuCl}_{2} \mathrm{~L}_{3}\left(\mathrm{H}_{2} \mathrm{O}\right)_{2}\right] 2 \mathrm{H}_{2} \mathrm{O}$ & Olive & $\begin{array}{l}140- \\
142\end{array}$ & $\begin{array}{c}37.76 \\
(37.12) \\
\end{array}$ & $\begin{array}{c}3.54 \\
(3.18)\end{array}$ & $\begin{array}{c}2.59 \\
(2.40)\end{array}$ & 71 & 29 \\
\hline$\left[\mathrm{RuCl}_{2} \mathrm{~L}_{4}\left(\mathrm{H}_{2} \mathrm{O}\right)_{2}\right] 5 \mathrm{H}_{2} \mathrm{O}$ & Olive & $96-98$ & $\begin{array}{c}57.81 \\
(57.24)\end{array}$ & $\begin{array}{c}4.17 \\
(4.09)\end{array}$ & $\begin{array}{c}7.10 \\
(6.96)\end{array}$ & 90 & 48 \\
\hline$\left[\mathrm{RuCl}_{2} \mathrm{~L}_{5}\left(\mathrm{H}_{2} \mathrm{O}\right)_{2}\right] 3 \mathrm{H}_{2} \mathrm{O}$ & Olive & $\begin{array}{l}160- \\
162\end{array}$ & $\begin{array}{c}40.16 \\
(39.79)\end{array}$ & $\begin{array}{c}4.49 \\
(4.13)\end{array}$ & $\begin{array}{c}2.60 \\
(2.26)\end{array}$ & 87 & 47 \\
\hline$\left[\mathrm{RuCl}_{2} \mathrm{~L}_{6}\left(\mathrm{H}_{2} \mathrm{O}\right)_{2}\right] 6 \mathrm{H}_{2} \mathrm{O}$ & Olive & $242 d$ & $\begin{array}{c}35.30 \\
(34.89)\end{array}$ & $\begin{array}{c}4.88 \\
(4.34)\end{array}$ & $\begin{array}{c}2.42 \\
(2.16)\end{array}$ & 69 & 25 \\
\hline$\left[\mathrm{RuCl}_{2} \mathrm{~L}_{7}\left(\mathrm{H}_{2} \mathrm{O}\right)_{2}\right] \mathrm{H}_{2} \mathrm{O}$ & Olive & $260 d$ & $\begin{array}{c}40.57 \\
(40.11)\end{array}$ & $\begin{array}{c}3.80 \\
(3.43)\end{array}$ & $\begin{array}{c}5.57 \\
(5.18)\end{array}$ & 73 & 44 \\
\hline
\end{tabular}


Table (III):Selected I.R. absorption bands of the ligands and their complexes

\begin{tabular}{|c|c|c|c|c|c|c|c|}
\hline \multirow{2}{*}{ Compounds } & \multirow{2}{*}{$v \mathrm{C}=\mathrm{O}$} & \multirow{2}{*}{$v \mathrm{C}=\mathrm{N}$} & \multirow{2}{*}{$v \mathrm{~N} \rightarrow \mathrm{O}$} & \multirow{2}{*}{$v \mathrm{M} \rightarrow \mathrm{O}$} & \multicolumn{3}{|c|}{ Coordinated water } \\
\cline { 6 - 8 } & & & & & $v(\mathrm{OH})$ & $\mathrm{r}(\mathrm{OH})$ & $\omega(\mathrm{OH})$ \\
\hline $\mathrm{L}_{1}$ & 1077 & 1595 & 1258 & ------ & ----- & ----- & ----- \\
\hline$\left[\mathrm{RuCl}_{2} \mathrm{~L}_{1}\left(\mathrm{H}_{2} \mathrm{O}\right)_{2}\right]$ & 1048 & 1593 & 1236 & 506 & 3432 & 830 & 648 \\
\hline $\mathrm{L}_{2}$ & 1105 & 1599 & 1356 & ----- & ----- & ----- & ----- \\
\hline$\left[\mathrm{RuCl}_{2} \mathrm{~L}_{2}\left(\mathrm{H}_{2} \mathrm{O}\right)_{2}\right] 4 \mathrm{H}_{2} \mathrm{O}$ & 1090 & 1598 & 1344 & 530 & 3421 & 839 & 648 \\
\hline $\mathrm{L}_{3}$ & 1139 & 1597 & 1255 & ----- & ----- & ----- & ----- \\
\hline$\left[\mathrm{RuCl}_{2} \mathrm{~L}_{3}\left(\mathrm{H}_{2} \mathrm{O}\right)_{2}\right] 2 \mathrm{H}_{2} \mathrm{O}$ & 1089 & 1597 & 1236 & 519 & 3423 & 827 & 633 \\
\hline $\mathrm{L}_{4}$ & 1163 & 1598 & 1346 & ---- & ----- & ----- & ----- \\
\hline$\left[\mathrm{RuCl}_{2} \mathrm{~L}_{4}\left(\mathrm{H}_{2} \mathrm{O}\right)_{2}\right] 5 \mathrm{H}_{2} \mathrm{O}$ & 1142 & 1597 & 1335 & 531 & 3382 & 827 & 656 \\
\hline $\mathrm{L}_{5}$ & 1170 & 1599 & 1261 & ----- & ----- & ----- & ----- \\
\hline$\left[\mathrm{RuCl}_{2} \mathrm{~L}_{5}\left(\mathrm{H}_{2} \mathrm{O}\right)_{2}\right] 3 \mathrm{H}_{2} \mathrm{O}$ & 1139 & 1597 & 1243 & 531 & 3346 & 849 & 670 \\
\hline $\mathrm{L}_{6}$ & 1163 & 1599 & 1253 & ----- & ----- & ----- & ----- \\
\hline$\left[\mathrm{RuCl}_{2} \mathrm{~L}_{6}\left(\mathrm{H}_{2} \mathrm{O}\right)_{2}\right] 6 \mathrm{H}_{2} \mathrm{O}$ & 1134 & 1597 & 1236 & 531 & 3422 & 826 & 689 \\
\hline $\mathrm{L}_{7}$ & 1215 & 1598 & 1283 & ----- & ----- & ----- & ----- \\
\hline$\left[\mathrm{RuCl}_{2} \mathrm{~L}_{7}\left(\mathrm{H}_{2} \mathrm{O}\right)_{2}\right] \mathrm{H}_{2} \mathrm{O}$ & 1164 & 1599 & 1264 & 503 & 3385 & 828 & 694 \\
\hline
\end{tabular}

Table (IV):Electronic spectra and magnetic moments for the synthesized complexes

\begin{tabular}{|c|c|c|c|c|c|}
\hline Complexes & $\begin{array}{c}{ }^{2} \mathrm{~T}_{2} \mathrm{~g} \rightarrow{ }^{4} \mathrm{~T}_{1} \mathrm{~g} \\
\lambda \max (\mathrm{nm})\end{array}$ & $\begin{array}{c}{ }^{2} \mathrm{~T}_{2} \mathrm{~g} \rightarrow{ }^{4} \mathrm{~T}_{2} \mathrm{~g} \\
\lambda \max (\mathrm{nm})\end{array}$ & $\begin{array}{c}{ }^{2} \mathrm{~T}_{2} \mathrm{~g} \rightarrow{ }^{2} \mathrm{~A}_{2} \mathrm{~g},{ }^{2} \mathrm{~T}_{1} \mathrm{~g} \\
\lambda \max (\mathrm{nm})\end{array}$ & $\begin{array}{c}\text { Charge } \\
\text { Transfer }\end{array}$ & $\begin{array}{c}\mu_{\text {eff }} \\
(\text { B.M.) }\end{array}$ \\
\hline$\left[\mathrm{RuCl}_{2} \mathrm{~L}_{1}\left(\mathrm{H}_{2} \mathrm{O}\right)_{2}\right]$ & 560 & 442 & 382 & 302 & 1.91 \\
\hline$\left[\mathrm{RuCl}_{2} \mathrm{~L}_{2}\left(\mathrm{H}_{2} \mathrm{O}\right)_{2}\right] 4 \mathrm{H}_{2} \mathrm{O}$ & 580 & 429 & 375 & 303 & 1.55 \\
\hline$\left[\mathrm{RuCl}_{2} \mathrm{~L}_{3}\left(\mathrm{H}_{2} \mathrm{O}\right)_{2}\right] 2 \mathrm{H}_{2} \mathrm{O}$ & 526 & 409 & 374 & 304 & 1.57 \\
\hline$\left[\mathrm{RuCl}_{2} \mathrm{~L}_{4}\left(\mathrm{H}_{2} \mathrm{O}\right)_{2}\right] 5 \mathrm{H}_{2} \mathrm{O}$ & 613 & 430 & 380 & 268 & 1.56 \\
\hline$\left[\mathrm{RuCl}_{2} \mathrm{~L}_{5}\left(\mathrm{H}_{2} \mathrm{O}\right)_{2}\right] 3 \mathrm{H}_{2} \mathrm{O}$ & 560 & 428 & 376 & 354 & 1.84 \\
\hline$\left[\mathrm{RuCl}_{2} \mathrm{~L}_{6}\left(\mathrm{H}_{2} \mathrm{O}\right)_{2}\right] 6 \mathrm{H}_{2} \mathrm{O}$ & 623 & 452 & 397 & 326 & 1.53 \\
\hline$\left[\mathrm{RuCl}_{2} \mathrm{~L}_{7}\left(\mathrm{H}_{2} \mathrm{O}\right)_{2}\right] \mathrm{H}_{2} \mathrm{O}$ & ---- & 460 & 387 & 337 & 1.74 \\
\hline
\end{tabular}

\section{REFERENCE}

1) Breuer E., Aurich H.G. and Nielson A., Nitrones,Nitronates and Nitroxides, John Wiely \& Sons, New York, 1989.

2) Wong E.H.H., Junkers T. and Kowollik C.b., Poly.Chem.,2011,2,1008.

3) Thiumalaikumar M. and Jegannathan . S., Potugaliae Electrochimica Acta,2011,29910,1.

4) Charaborty B., Chhetri .M.S. Chhetri S.Katley and .Samanta A ,Ind. J. Chem.,2010,49B,209.

5) Amutha C., Saravanan .S. Saravanan,.Dhandapani P.S., Muthusbramanian . S. and Sivasubramanian .S, Ind. J. Chem.2008,47B,276.

6) Dondas . H.A., Cumins ,J.E., Grigg .R. and. Thornton P, Tetrahedron,2001,57,7951. 
7) Grigorev I.A., ARKIVOC ,2009,(IV),136.

8) Villamena F.A., Dickman .M.H and D.R.Christ , Inorg. Chem.,1998,37,1446.

9) Lee J., Twamley .B. and Richter . G.B.Richter Addo,Chem.Commun.,2002,380

10) Kannan. S,.Usman A and .Fun H.K,Polyhedron,2002,21(23),2403.

11) Yavus S., Ozkan H., Colak N, and Yildirir Y.,Molecules,2011,16,6677.

12) West P.R. and Davis .G.C.Davis ,J. Org. Chem.,1989,54,5176.

13) Geary W.J.,Chem.Abst.,1974,75.

14) Canpolat E, and Kaya M.,Turk . J.Chem.,2005,29,409.

15) Mounika $K$, Anupama $B$, Pragathi $J$ and Gyanakumari C,J.Sci.Res.,2010,2(3),513.

16) Al-Allaf . T.A.K. and .Omer A.O.,Pure and Applied Sciences, 1993,20,53.

17) Ahmed .A.H, Omran .A.A, and El-Sherbiny G.M.,J .Appl .Sci .Res.,2006,2(1),44.

18) Nakamoto K, Infrared Spectra of Inorganic and Coordination Compounds, $15^{\text {th }}$ Ed, John Wiely \&Sons, 1988,183.

19) Sharma.V.K., Srivastava S, and Srivastava A, Bioinorg. Chem. and Appl.,2007, Hindawi Publishing Corporation, Article, 10.

20) Chitilappilly P.S. and Yusuf K.K.M, Ind .J. Chem.,2008,47A,848.

21) El-Hindawy A.M., Al-Madfa .H.A, El-Bindary.A. , Abdul-Ghany S. and Diab .M ,Qatar Univ. Sci .J.,1994,14(C), 80. 